\title{
Post-Surgery Subcutaneous Seeding of Laryngeal Squamous Cell Carcinoma: A Rare Case
}

\author{
Yongquan Jiang ${ }^{a}$ Wanxin Cao ${ }^{a}$ Yuanbo Luo ${ }^{b}$ Ji Xua Ying $\mathrm{Li}^{a}$ \\ Jiping $\mathrm{Li}^{\mathrm{a}}$ \\ aDepartment of Otolaryngology, Renji Hospital, School of Medicine, Shanghai Jiaotong \\ University, Shanghai, China; ${ }^{b}$ School of Medicine, Shanghai Jiaotong University, Shanghai, \\ China
}

\section{Keywords}

Cancer $\cdot$ Laryngeal squamous cell carcinoma $\cdot$ Subcutaneous seeding

\begin{abstract}
Laryngeal squamous cell carcinoma (LSCC) is the most common malignant head and neck cancer, with a $40 \%$ recurrence rate in the first 3 years after radical treatment. Recurrence of LSCC mostly comprises lymphogenous metastasis, hematogenic metastasis, and locoregional recurrence, while LSCC seeding is rarest: there are only 4 cases reported in PubMed, and none of them is one of subcutaneous seeding. We report a case with post-surgery subcutaneous seeding of LSCC. The final biopsy demonstrated that the subcutaneous seeding of the LSCC was $2 \mathrm{~cm}$ away from the primary lesion, with no recurrent foci observed in the larynx and tracheostoma and little relation to the primary lesion. Thus, we drew the conclusion that LSCC surgeries should stick to the principle of the non-tumor technique to prevent subcutaneous seeding.

(C) 2021 The Author(s).

Published by S. Karger AG, Basel
\end{abstract}

\section{Introduction}

As one of the most common malignant head and neck cancers, $85-95 \%$ of malignant laryngeal cancers are squamous cell carcinomas (SCCs) [1]. In 2018, about 13,150 patients were diagnosed with laryngeal SCCs (LSCCs), 3,740 of whom are dead [2]. Despite great progress in LSCC treatment having been witnessed in the past years, in the first 3 years after radical treatment, the recurrence rate can be as high as $40 \%$ [3].

\section{Karger ${ }^{\prime \prime}$}




\section{Case Reports in Oncology}

\begin{tabular}{l|l}
\hline Case Rep Oncol 2021;14:568-572 \\
\hline DOI: 10.1159/000510361 & $\begin{array}{l}\text { @ 2021 The Author(s). Published by S. Karger AG, Basel } \\
\text { www.karger.com/cro }\end{array}$ \\
\hline
\end{tabular}

Jiang et al.: Post-Surgery Subcutaneous Seeding of LSCC

Fig. 1. Supracricoid partial laryngectomy + cricohyoidoepiglottopexy was performed in July 2019. The margins were disease free (arrows) and no sign of lymphadenopathy was detected.

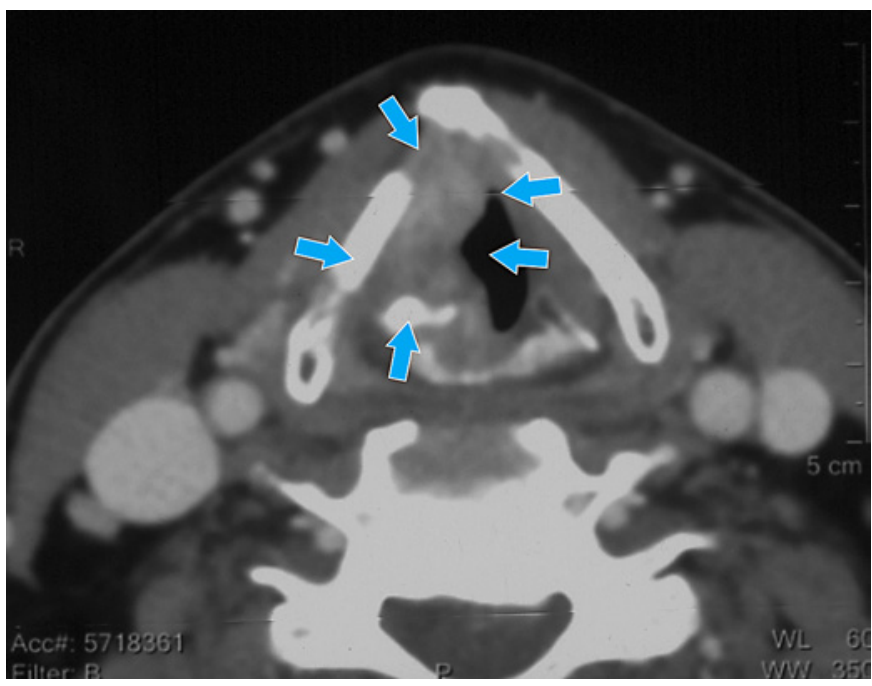

Fig. 2. Magnetic resonance imaging in October 2019 showed a $4 \times 5 \mathrm{~cm}$ mass lesion in the left anterior cervical region, with involvement of the skin and subcutaneous tissue but leaving out the larynx.

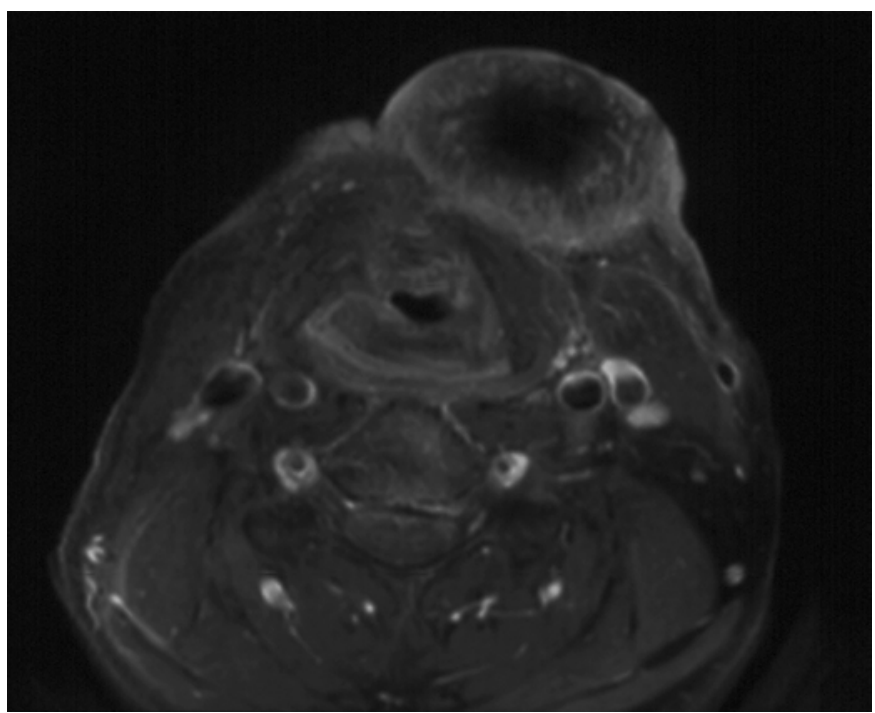

Metastasis of laryngeal cancer is an important factor for the high recurrence rate, which usually involves the lymphogenous pathway. Less commonly, metastases to the lungs, bone, liver, and skin through the hematogenic pathway are seen. The majority of distant metastases occur within the first 2 years after diagnosis, whereas locoregional recurrence is usually seen within the first year [4].

The rarest type is LSCC seeding; there are only 4 cases reported in PubMed [5-7]. Two cases entailed seeding to the gastrointestinal tract and 2 cases involved tracheal seeding. No subcutaneous seeding has ever been encountered (search strategy: "seeding" and "laryngeal cancer" were searched in the title, keywords, and abstract). Therefore, we present a case of glottic laryngeal cancer with subcutaneous seeding.

\section{Case Report}

A 55-year-old man was diagnosed with T3N0M0 SCC of the right glottic larynx in July 2019. Surgery (supracricoid partial laryngectomy + cricohyoidoepiglottopexy + tracheostomy) was performed. The margins were disease free and no sign of lymphadenopathy 


\section{Case Reports in Oncology}

\begin{tabular}{l|l}
\hline Case Rep Oncol 2021;14:568-572 \\
\hline DOI: 10.1159/000510361 & $\begin{array}{l}\text { ○ 2021 The Author(s). Published by S. Karger AG, Basel } \\
\text { www.karger.com/cro }\end{array}$ \\
\hline
\end{tabular}

Jiang et al.: Post-Surgery Subcutaneous Seeding of LSCC

Fig. 3. Physical examination in December 2019 revealed a fistulized mass (about $14 \times 16 \mathrm{~cm}$ in size) in the region inferior to the submental margin, superior to the supraclavicular fossae, and medial to both sides of the sternocleidomastoid muscles.
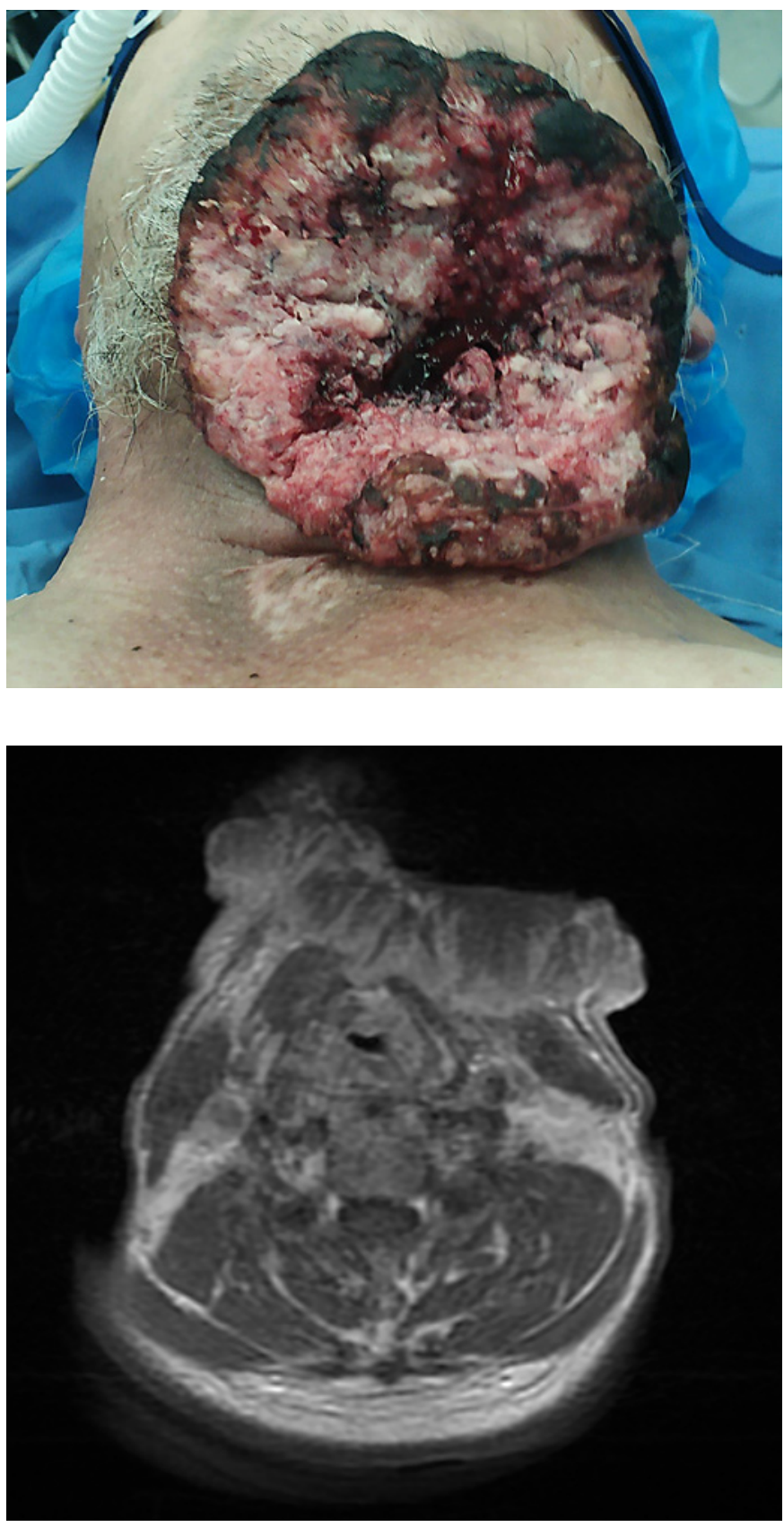

Fig. 4. MRI in December 2019 showed involvement of the skin, subcutaneous tissue, and strap muscles.

was detected. The final pathological examination confirmed a moderately to highly differentiated SCC. Two weeks postoperatively, the patient was decannulated, with follow-up after discharge. In September 2019, a mass was found in the left anterior cervical region, which was $1 \times 1.5 \mathrm{~cm}$ in size and $2 \mathrm{~cm}$ away from the initial tracheostoma according to the physical examination. In October 2019, the mass had progressed rapidly with ulceration. Magnetic resonance imaging (MRI) showed a $4 \times 5 \mathrm{~cm}$ mass lesion in the left anterior cervical region, with involvement of the skin and subcutaneous tissue but leaving out the larynx. The biopsy confirmed a highly differentiated SCC. The patient took herbs (details unknown) himself for about 40 days instead of receiving surgery, chemotherapy, or radiotherapy (Fig. 1, 2). 
The patient was admitted to our center (Shanghai Jiaotong University affiliated Renji Hospital) due to a large festered mass in the cervical region in December 2019. Physical examination revealed a fistulized mass (about $14 \times 16 \mathrm{~cm}$ in size) in the region inferior to the submental margin, superior to the supraclavicular fossae, and medial to both sides of the sternocleidomastoid muscles. MRI showed the involvement of the skin, subcutaneous tissue, and strap muscles. Taking the medical history, physical examination, and MRI into consideration, a recurrent SCC was suspected. Strictly following the NCCN 2019 [8], the patient was arranged for surgery (extended laryngeal cancer resection + total laryngectomy + latissimus dorsi flap). The pathological examination confirmed the invasion of the tumor into subcutaneous tissue and strap muscles, with no recurrent foci observed in the larynx and tracheostoma. The patient was disease free during the 5-month follow-up (Fig. 3, 4).

\section{Discussion}

In this report, we recognized a case of subcutaneous seeding presumably caused by laryngectomy, described for the first time in patients after malignant head and neck tumor operation. LSCC commonly spreads to cervical lymph nodes, and distant metastasis usually involves the lung, while subcutaneous seeding has never been reported.

In our case, the recurrent tumor had the same pathology as the primary lesion; however, the location of the recurrent lesion had little relation to the primary lesion according to both MRI and final biopsy during the surgery. Recurrence generally has a 2-month delay, while the other types of metastasis generally need 3-68 months to develop [9]. Based on these three pieces of evidence, subcutaneous seeding caused by the initial laryngectomy was taken into consideration.

Neoplastic seeding caused by operations has already been reported in various cancers, including LSCC, hepatocellular carcinoma, non-small cell lung carcinoma, renal cell carcinoma, breast cancer, and thyroid carcinoma [10-17]. The operations here are needle biopsy, tracheostomy, and percutaneous endoscopic gastrostomy. Surgeries, like supracricoid partial laryngectomy, have a larger interface with the tumor tissue, which makes patients more liable to neoplastic seeding. We postulate that in the presented case, LSCC cells were implanted accidently during the surgery due to a carelessly followed non-tumor technique principle, as the recurrent tumor discontinued with the primary tumor in both MRI and final biopsy during the removal of the tumor. Based on this postulation, we draw the conclusion that LSCC has the potential to seed subcutaneously, which emphasizes the importance of the non-tumor technique principle.

\section{Statement of Ethics}

The patient has given his written informed consent to the publication of his case (including images).

\section{Conflict of Interest Statement}

The authors have no conflicting interests to declare.

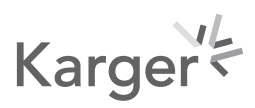




\section{Funding Sources}

There were no funding sources.

\section{Author Contributions}

Yongquan Jiang designed the research study. Yongquan Jiang, Wanxin Cao, Ji Xu, and Ying Li treated the patient and acquired the clinical data. Yongquan Jiang, Yuanbo Luo, and Wanxin Cao wrote the manuscript. Jiping Li supervised the study.

\section{References}

1 Unsal AA, Kılıç S, Dubal PM, Baredes S, Eloy JA; EUROCARE-5 Working Group. A population-based comparison of European and North American sinonasal cancer survival. Auris Nasus Larynx. 2018;45(4):815-24.

2 Siegel RL, Miller KD, Jemal A. Cancer statistics, 2016. CA Cancer J Clin. 2018;66(1):7-30.

3 Brandstorp-Boesen J, Sørum Falk R, Folkvard Evensen J, Boysen M, Brøndbo K. Risk of recurrence in laryngeal cancer. PLoS One. 2016;11(10):e0164068.

4 Vural A, Avcı D, Çağlı S, Yüce İ, Arlı T. Gluteus medius muscle metastasis of squamous cell carcinoma of larynx: a rare case. Braz J Otorhinolaryngol. 2020;86(Suppl 1):23-5.

5 Siddiqi AM, Hamilton RD, Minocha A. Malignant seeding of percutaneous endoscopic gastrostomy tract in patient with head and neck cancer. Am J Med Sci. 2008;336(3):291-2.

6 Thorburn D, Karim SN, Soutar DS, Mills PR. Tumour seeding following percutaneous endoscopic gastrostomy placement in head and neck cancer. Postgrad Med J. 1997;73(861):430-2.

7 Clayman G, Cohen JI, Adams GL. Neoplastic seeding of squamous cell carcinoma of the oropharynx. Head Neck. 1993;15(3):245-8.

8 NCCN. Head and Neck Cancer (Version 2.2019). 2019. Available from: https://www.nccn.org/professionals/ physician_gls/default.aspx\#head-and-neck.

9 Cui J, Wang L, Tan G, Chen W, He G, Huang H, et al. Development and validation of nomograms to accurately predict risk of recurrence for patients with laryngeal squamous cell carcinoma: cohort study. Int J Surg. 2020; 76:163-70.

10 Julie Brousseau V, Taylor SM, Trites J. Neoplastic seeding at the tracheotomy site: report of two cases. J Otolaryngol Head Neck Surg. 2008;37(1):E15-8.

11 Santiago L, Adrada BE, Huang ML, Wei W, Candelaria RP. Breast cancer neoplastic seeding in the setting of image-guided needle biopsies of the breast. Breast Cancer Res Treat. 2017;166(1):29-39.

12 Scotti V, Di Cataldo V, Falchini M, Meattini I, Livi L, Ugolini D, et al. Isolated chest wall implantation of non-small cell lung cancer after fine-needle aspiration: a case report and review of the literature. Tumori. 2012;98(5): 126e-9e.

13 Horn T, Seidl S, Gschwend JE, Kübler H. Implantation metastasis of prostate cancer in a suprapubic cystostomy tube needle tract. Prostate Cancer Prostatic Dis. 2010;13(3):292-4.

14 Stokes ME, Thompson D, Montoya EL, Weinstein MC, Winer EP, Earle CC. Ten-year survival and cost following breast cancer recurrence: estimates from SEER-Medicare data. Value Health. 2008;11(2):213-20.

15 Volpe A, Kachura JR, Geddie WR, Evans AJ, Gharajeh A, Saravanan A, et al. Techniques, safety and accuracy of sampling of renal tumors by fine needle aspiration and core biopsy. J Urol. 2007;178(2):379-86.

16 Ito Y, Asahi S, Matsuzuka F, Nakamura Y, Amino N, Miyauchi A. Needle tract implantation of follicular neoplasm after fine-needle aspiration biopsy: report of a case. Thyroid. 2006;16(10):1059-62.

17 Ito Y, Tomoda C, Uruno T, Takamura Y, Miya A, Kobayashi K, et al. Needle tract implantation of papillary thyroid carcinoma after fine-needle aspiration biopsy. World J Surg. 2005;29(12):1544-9.

\section{Karger'k}

